\title{
Rights-based Approaches and Bilateral Aid Agencies: More Than a Metaphor?
}

\author{
Laure-Hélène Piron*
}

It could be argued that the rights based approach ... is no more than a metaphor; a concept that catalyses a set of values into a phrase that many people can adopt and adapt. It is a general statement in favour of equitable development, involving widespread participation of those with no direct control of, or access to, the power of the state... If we still take rights as a legal concept then much of what passes as rights based is unlikely to be successful because there are often no state bodies committed to meeting the obligations implied. There is also a sense in that the "emperor has no clothes" as there are too many people arguing about the details of what a rights approach should be and how it should be operationalised. Meanwhile, this is happening in the absence of any clear idea of what it is they are engaging with. (Pratt 2003: 2)

\section{Introduction}

Brian Pratt's statement that the rights-based approach is 'no more than a metaphor; a concept that catalyses a set of values into a phrase that many people can adopt and adapt' (Pratt 2003: 2) is a damning condemnation of what has been correctly described as a growing 'rights-based approach industry' (Theis 2004: xiii). It echoes Michael Ignatieff's critique of rights-based approaches as analytically confused, verging on the meaningless (Ignatieff 2003). At the same time, Peter Uvin has issued a strong defence, describing it as 'the only approach [that] contains the potential to provide the necessary changes in current development practice' (Uvin 2004: 178).

Are rights-based approaches no more than a metaphor, or do they point to a consensus around a set of desirable changes in the policies, programmes and behaviour of aid agencies? This article argues that a common core can be identified and some transformations are under way. However, much remains to be done to influence not just the behaviour of individual agencies, but also the international consensus on aid and the place of human rights within it.

This article reviews rights-based approaches in development aid agencies. It begins by identifying some of the ways in which agencies can incorporate human rights into their policies and activities. It then examines the extent to which rights-based approaches can be said to have been adopted and the factors that facilitate or constrain this transformation. Finally, it points to some of the current challenges facing agencies attempting to close the gap between their rights-based approaches and mainstream development policy and practice.

This article principally examines bilateral agencies. This is both for practical reasons (narrowing the range of agencies reviewed) and also because these agencies are government departments, sometimes belonging to Ministries of Foreign Affairs or independent Ministries. As such, they should be more directly obligated under the international human rights regime than international or non-governmental organisations (NGOs) and can significantly shape the aid discourse.

\section{International context}

The end of the Cold War and the various UN conferences of the 1990s, in particular the 1993 Vienna World Conference on Human Rights (UN 1993), created the context for the introduction of human rights in bilateral aid agencies policy frameworks during the 1990s, often starting with foreign policy statements by Ministries of Foreign Affairs, followed a few years later by specific agency 
documents. In many cases, human rights were associated with democracy and the rule of law and made a new objective of development cooperation (CIDA 1996; Swedish Ministry for Foreign Affairs 1999). Some agencies had already been responding to human rights situations, such as abuses in Latin America, anti-apartheid efforts in South Africa or the Rwanda genocide (Baaré et al. 1999; Carothers 1999). The official statements made human rights a "normal" topic of aid work, emphasising the importance of positive measures and opening the way for a rise in more political activities.

This trend accelerated in the late 1990s and early 2000s, with a number of international events creating a momentum, such as: the 1997 commitment to "mainstream" human rights into all the UN activities showing the need for institutional reforms to complement policy commitments (UN 1997); a number of international conferences on human rights and development, including in Norway and Sweden (UNDP et al. 1998; Frankovits and Earle 2000); the 1998 anniversary of the Universal Declaration on Human Rights serving as a catalyst for further public pronouncements; the 2000 Human Development Report on human rights and human development (UNDP 2000); and UN interagency meetings in Princeton and Stamford to develop a UN inter-agency position (UN 2003).

The way in which human rights have been integrated into agencies' policy frameworks and programmes varies. The remainder of this article reviews these different approaches.

\section{The right to development}

As Cornwall and Nyamu-Musembi (this issue) note, the 1986 Declaration on the Right to Development was one of the earliest attempts to establish a clear relationship between human rights and development assistance. However, it is striking how discussions on the right to development do not form a central part of current discourses on human rights in aid agencies and cannot be said to have directly informed the adoption of rights-based approaches (Piron 2002). Some agencies' statements do refer to the right to development, most recently Germany's action plan (German Federal Ministry for Economic Cooperation and Development 2004). However, in general, the debates are being kept separate. This is so at a "physical" and "professional" level: Right to Development meetings take place among diplomats at the UN in Geneva or New York; they rarely involve aid agency officials (at least not much beyond assisting their diplomatic colleagues in these political discussions).

This separation between the discourses is certainly in part due to the controversy surrounding the international legal obligations on wealthier countries that might derive from a legally binding convention. Donor countries do not wish to be legally obliged to provide aid; at present they do so on political, moral or self-interested grounds. Though a number of commitments in line with what the Declaration on the Right to Development would call for, such as increasing aid volumes or improving the coherence of aid with other international policies, can be found in leading aid policy documents, such as the 8th Millennium Development Goal (UN 2001) or as a result of the Monterrey Consensus (UN 2002), donors do not wish these commitments to be associated with human rights obligations and any form of legally enforceable responsibility.

Yet, resistance is not only to be found on the part of donor governments. The extreme politicisation of UN debates includes the rejection by Southern governments of seeing the right to development as in any way related to rights-based approaches. This is in part for fear of de-prioritising the call for global governance reform and introducing human rights conditionalities attached to aid, but also because some do not wish to put too much emphasis on the need for domestic efforts for the protection and promotion of all human rights, which the Declaration also calls for (Piron 2002).

The separation of the two discourses is thus physical, professional and political, but is also explained by conceptual and operational factors. Aspects of the 1986 Declaration are still highly relevant for aid policies, in particular the strong definition of the right to 'active, free and meaningful participation' and the clear statement of the indivisibility and interdependence of all human rights. It can be used as an entry point to push for greater donor accountability and reciprocal relations with developing countries and greater coherence between aid and other policies (Piron 2004). However, after over 30 years of existence, the concept still lacks clarity and, as a result, operational relevance for agencies. There is still no agreement on who the "duty-holders" and "rights-bearers" are and how progress is to be measured; and discussions are often out of touch with the reality of aid practice. 
In contrast with rights-based approaches, the right to development has failed to capture the public imagination beyond UN corridors and remains, for the time being, 'buried in some obscure subcommittee' (Uvin 2004: 43).

\section{Rhetorical commitments}

While the right to development has failed to take root in agency discourse, human rights have increasingly permeated their language. As noted above, the 1990s saw a rise in the number of statements often making reference to the Vienna Declaration's recognition that 'democracy, development and respect for human rights and fundamental freedoms are interdependent and mutually reinforcing' and to the interdependence and interrelatedness of all human rights (UN 1993).

Some were, however, only rhetorical commitments, claiming that all aid work, by definition, would contribute to the realisation of human rights. For example, AusAid stated that 'At the broadest level, therefore, the whole Australian aid program contributes to the realisation of human rights' (Government of Australia 1998). This position is most clearly found in the World Bank description of itself as directly contributing to the fulfilment of many of the economic and social rights articulated in the Universal Declaration (e.g. primary education, health care) and, indirectly, through its governance activities (e.g. anti-corruption, judicial reform), to building environments in which people are better able to pursue a broader range of human rights (World Bank 1998: 3), without committing to any new activities, institutional reforms or a more liberal interpretation of its Articles of Agreement. The Bank did not wish to be held accountable under the international human rights framework, nor did the governments that sit on its Board.

\section{Towards mainstreaming}

Beyond rhetorical commitments, agencies have identified several ways in which they can integrate human rights into their work (see e.g. CIDA 1996; SDC 1997; Sida 1997a; Government of Australia 1998; DFID 2000b; NORAD 1999; Finnish Ministry for Foreign Affairs 2000; Danida 2003). This includes:

- Policy dialogue with governments on how they can best meet their human rights obligations (in collaboration with diplomatic services).
- New programming to build the capacity of governments and civil society actors to protect and promote human rights (often referred to as "positive measures" and often in governance, a new field).

- Dedicated human rights funds at a global, regional or country level (e.g. Canada Funds, DFID Good Governance Funds, AusAid Fund).

- Support to the UN system in its efforts to develop a human rights-based approach (e.g. funding for UN inter-agency meetings).

- Working with international and local human rights NGOs (e.g. Nordic agencies funding through NGOs such as the Danish Centre for Human Rights).

- Addressing the negative impacts of aid (the "do no harm principle"), which requires human rights impact assessments and monitoring systems (e.g. NORAD human rights assessments handbook in 2001).

- Suspension of aid in extreme circumstances (e.g. suspension of assistance to Myanmar following the suppression of pro-democracy movement) or limiting aid to working with civil society organisations, through the United Nations, or for humanitarian assistance.

- Commitment to policy coherence with other branches of governments (e.g. especially coordination with Ministry for Foreign Affairs), other governments and international agencies.

This menu of possible interventions, including both positive measures and negative conditionalities, is at times complemented by a specific commitment to mainstream human rights across an organisation. Human rights are thus seen as both a specific policy or programming objective and also a cross-cutting theme for other programmes and policy areas. The impact of such policy statements is illustrated by the case study of the Swiss Agency for Development and Cooperation (SDC) - see Box 1.

\section{Rights-based approaches}

Discussions of human rights mainstreaming have now been replaced by references to "human rightsbased" or rights-based approaches. This shift in the debate points to a recognition of the need for agencies to seriously undertake internal institutional changes rather than simply have new human rights activities or dialogue. More significantly, it refers a 


\section{Box 1: From Policy Guidelines to Operationalisation in SDC}

In 1993, human rights, democracy and the rule of law were made one of the five Swiss foreign policy priorities. The Swiss Agency for Development and Cooperation (SDC), a department of the Federal Ministry of Foreign Affairs, issued human rights guidelines in 1997.

An evaluation of their impact found they were seen as having been highly relevant at the time, the product of a cross-governmental working group responding to both foreign policy and the practical needs of SDC staff. However, simply issuing a policy statement had its limitations: few SDC measures to accompany the guidelines provided any operational guidance by 2003. Many different interpretations of the relevance of meaning of human rights for development cooperation remained. The SDC has increased its expenditure on human rights activities, but it remains a very small amount (estimated from 1.4 per cent in 1999 to 2.6 per cent in 2002 for bilateral aid but rising from 14 per cent to 22 per cent for transition countries), mostly concerned with civil and political rights projects and associated with a general rise in good governance activities. Systems and procedures were not changed, human rights dialogue was seen as difficult and Switzerland has reviewed its approach to human rights conditionality, considered not to have been consistently applied.

Following the reorganisation of SDC's policy branch, human rights have been located in the Governance Division and a new focal point has been very active. This has involved highlighting the equal importance of social and economic rights and the links between SDC's fundamental values and its commitment to poverty reduction. Discussions of other donors' initiatives, as well as staff training and the provision of direct advice to country programmes, are helping SDC move towards making human rights inform the way in which aid is delivered. SDC is presently considering whether to officially adopt a rights-based approach.

Source: Piron and Court (2003); SDC (1997; 2004); Swiss Government (1993).

systematic transformation in the way in which the goal of development is conceptualised, objectives set and monitored, strategies developed and the relationship with partners managed (Piron 2004). AusAid, explaining its decision not to adopt a rightsbased approach, states: 'the basic principle of a rights-based approach is that it involves not only mainstreaming human rights within aid programs and activities, but uses the achievement of specific human rights objectives as the foundation for aid policy implementation' (AusAid 2001). It is this radical call that makes rights-based approaches more challenging than previous efforts to integrate human rights.

The starting point, in most agencies' statements, is the recognition that human rights standards and principles need to guide development cooperation as part of donor governments overall relationships with their partners under the international human rights regime. Additional arguments have been put forward to show the operational and analytical benefits of such a change. For example, a review of DFID initiatives highlighted the following perceived benefits (Piron and Watkins 2004):
- A rights-based approach provides a normative framework to guide development aid, setting out clear international standards and clarifying both the rights of individuals and the obligations of states, based on an international consensus. Donors can support actors using these standards to challenge the status quo (e.g., civil society organisations can appeal to them when lobbying for policy change), improve the performance of government bodies (e.g., standards associated with a fair trial); regulate the behaviour of nonstate actors (labour standards) or guide the allocation of state resources (social protection).

- People are placed at the centre of development processes, no longer seen as beneficiaries of development projects with needs, but as active citizens with rights and entitlements. As a result, aid can be seen as contributing to the transformation of state-society relations, enhancing government accountability to the poor and empowering all citizens to claim their rights and participate in decision making, thus strengthening the "social contract". Politics and power relations are thus put at the centre of programming analysis and 
interventions, rather than seen as negative "risk" factors attached to projects.

- It draws attention to discrimination and equality of outcomes and opportunities for vulnerable and marginalised groups. This can lead to more effective poverty eradication by demonstrating that certain groups may be systematically excluded from the benefits of development. Donors can support appropriate policy or institutional responses on the part of governments (such as affirmative action or improved data collection) or the mobilisation of these groups.

- It can help improve accountability mechanisms for a whole range of actors, ranging from domestic political accountability structures (e.g. parliaments), judicial or quasi-judicial mechanisms (e.g. courts, human rights commissions), or community-based initiatives (e.g. community scorecards or public hearings).

- It can influence how aid is designed and delivered, for example highlighting the negative as well as positive impacts of aid, or encouraging innovations that engage both donors and partner governments in a more open dialogue around human rights in a partnership-based, "contractual" framework.

\section{Different understandings of rights-based approaches}

There are differences in the way in which rights-based approaches are defined, legitimising, in part, Pratt's claim that discussions on rights-based approaches are 'happening in the absence of any clear idea of what it is they are engaging with'. The main distinction can be described as one between 'empowerment' and 'legalistic' approaches (Piron 2003), referring to Philip Alston's identification of the two strengths of the human rights discourse: (1) to serve as an inspirational, mobilising force in support of a particular agenda, and (2) to facilitate access to a range of legal norms and enforcement mechanisms (Alston 1985: 512-13). A distinction, however, does not mean an opposition and the point emphasised here is that both these dimensions are important to rights-based programming, though they are emphasised to a lesser or greater degree by aid agencies.

A human rights-based approach is explicitly based on the international human rights system, including the human rights norms, standards and principles as set out in UN, International Labour Organization or regional declarations, conventions and other instruments. The May 2003 "UN interagency common understanding" provides the best definition of this approach which characterises the objective of development assistance as the realisation of human rights (UN 2003). This aims to move the current consensus beyond defining the objective of development assistance as poverty reduction (as agreed in the Millennium Declaration, UN 2000) and making human rights constitutive of this goal, rather than an add-on or an element included because of its instrumental value.

A "rights-based approach" is often only used as a short-hand for a "human rights-based approach" (as in this article), but sometimes implies a certain

\section{Box 2: UN Inter-agency Common Understanding on a Human} Rights-based Approach

All programmes of development cooperation, policies and technical assistance should further the realisation of human rights as laid down in the Universal Declaration of Human Rights and other international human rights instruments.

- Human rights standards contained in and principles derived from, the Universal Declaration of Human Rights and other international human rights instruments guide all development cooperation and programming in all sectors and in all phases of the programming process.

- Development cooperation contributes to the development of the capacities of "duty-bearers" to meet their obligations and/or of "rights-holders" to claim their rights.

- The human rights principles identified in this agreement are: universality and inalienability; indivisibility; inter-dependence and interrelatedness; equality and non-discrimination; participation and inclusion; accountability and rule of law.

Source: United Nations (2003). 


\section{Box 3: DFID: Rights, Participation and Poverty Reduction}

The election of a new Labour government in 1997, committed to an ethical foreign policy, with a new Secretary of State for International Development committed to poverty reduction and prioritising economic and social rights led to the DFID 1997 and 2000 White Papers making references to human rights. The 2000 Target Strategy Paper established three principles: "participation", "inclusion" and "fulfilling obligations" to operationalise DFID's new rights-based approach. By contrast to other bilateral agencies, in particular Nordic ones, which had firmly put human rights in a governance "box", DFID's policy built on and consolidated its use of participatory approaches, highlighting the empowerment of poor people to claim their rights. Instead of putting the international human rights framework (captured under the 'obligations' principle) as the umbrella for the approach, participation and inclusion were prioritised.

A recent review showed that DFID had undertaken a very wide range of relevant activities, including: funding UN agencies; piloting new participatory rights assessment methodologies; country programmes (in particular in Latin America) structured around participation and inclusion; refocusing support to civil society; encouraging participatory approaches to social sectors (e.g. in school management) and in relation to Poverty Reduction Strategies.

However, systems and procedures were not amended, for example to introduce human rights impact assessments or systematic human training and there remains internal resistance to the approach. Interestingly, some changes in DFID's governance policies and programmes where not "labelled" as rights-based though they were consistent with the approach. For example, DFID's new safety, security and accessible justice policy emphasises outcomes for poor people and the fairness and accessibility of institutions, rather than their organisational effectiveness. DFID's 'Drivers of Change' analytical framework, aiming to better understand the context of aid interventions, notes the importance of moving towards a "citizenship model". Neither approaches, however, made much explicit use of the international human rights framework.

Source: Piron (2003); Piron and Watkins (2004).

distance from the international human rights system, seen as having limited practical relevance for aid agencies or the lives of poor people (DFID 2000b) or as representing Western values. It can be associated with what Cornwall and Nyamu-Musembi (this issue) describe as 'a way of reframing participation' or by Pratt (above) as 'a general statement in favour of equitable development'. The explicit reference to "human" rights is removed, thus principally referring to citizenship rights, sometimes associated with a focus on activities that support the empowerment of the very poorest or civil society mobilisation rather than structural or institutional reforms.

While in most bilateral aid agencies human rights have been associated with a rise in governance initiatives aiming at state reform, DFID provides an interesting counter-example where "rights-based" programming has been aimed at promoting participation and inclusion and less explicitly related to DFID's new approaches to governance (Piron 2003) (see Box 3 for further details).
This difference in emphasis is also highlighted by the UN common understanding distinction between "unique" elements (what makes the approach different from other approaches, for example analysis of rights and obligations and using human rights standards and principles) and "essential" ones (required good programming practices shared with other approaches, such as local ownership or empowerment).

The tension between these two dimensions explains Pratt's concern that it is only a "metaphor" for whatever is valued, echoing Ignatieff's criticism of the analytical weakness when the rights language only becomes a buzz word, a vague aspirational claim to resources (Ignatieff 2003). Indeed, rightsbased approaches would seem to lose their credibility when they are used to champion whatever change is seen as desirable. However, grounding them in the international human rights framework sets out clearly: the values behind this discourse, precise commitments, especially for a minimum level of 
Table 1: Perceived Strengths and Weaknesses of Different Approaches

\begin{tabular}{|c|c|c|}
\hline & Human rights-based approach & Rights-based approach \\
\hline Strengths & $\begin{array}{l}\text { Normative approach based on } \\
\text { the international human rights } \\
\text { system. Builds on states' existing } \\
\text { obligations and international } \\
\text { consensus-building processes. } \\
\text { Subjects state power to } \\
\text { (international) law. Human rights } \\
\text { commitments are more precise } \\
\text { than general calls for } \\
\text { accountability or participation. } \\
\text { Covers all human beings. Human } \\
\text { rights are also associated with } \\
\text { non-state obligations. }\end{array}$ & $\begin{array}{l}\text { Puts power relations explicitly at } \\
\text { the centre of the analysis. } \\
\text { Emphasises the political nature of } \\
\text { the approach, in particular the } \\
\text { "social contract" between the } \\
\text { state and citizens empowered to } \\
\text { claim their rights. Does not } \\
\text { depend on international or legal } \\
\text { systems to codify or enforce } \\
\text { rights. New rights can be } \\
\text { identified locally, regardless of the } \\
\text { international framework (e.g. "the } \\
\text { right to be heard"). Seen as more } \\
\text { responsive to local contexts and } \\
\text { priorities of poor people. }\end{array}$ \\
\hline
\end{tabular}

Weaknesses

well-being and the mechanisms to monitor and put them into practice, thus offering 'the immediate possibility of establishing accountability on the part of the government involved' (Alston 1998: 106).

A "right" is in itself value neutral; and an approach based on realising rights can mean simply ensuring that existing legislation is put into practice. There are many kinds of existing statutory or customary rights that proponents of rights-based approaches would like to see removed, for example discriminatory legislation on the basis of gender or race, or regulations acting as institutional barriers to accessing public services. The international human rights system, flawed as it may be, provides an explicit and shared normative framework against which to assess existing laws, policies, programmes or social relations. Even if advocates of rights-based approaches distrust the relevance of the international human rights system, or are disappointed by the inability of domestic state institutions to turn human or statutory rights into a reality, they too share a normative framework based on fundamental values which needs to be made explicit.

Table 1 provides a summary of the perceived strengths and weaknesses of these different interpretations.

Different attitudes towards law, politics and society would thus seem to be behind the human rights/rights-based distinction. In fact, the strength of the current rights-based discourse is that it brings together state-centred and society-centred interventions, highlighting that for states to meet their obligations and citizens to realise their rights, both state institutions need to be strengthened and citizens need to be empowered. As noted by the Dutch Advisory Council on International Affairs 
(2003: 35), "human rights play a protective and emancipatory role ... they fulfil a protective function by providing legal and political protection in situations in which human dignity itself is at stake. In addition, from an emancipatory point of view, they encourage people whose rights have been violated to take control and push for social change'.

This congruence between the different elements of rights-based approaches is illustrated by the choice of "human rights principles" adopted by agencies to operationalise the approach in their programming. In addition to those that emphasise international standards as a starting point, three categories of principles emerge (Piron 2004): (1) equality and non-discrimination, as well as (2) participation (e.g. empowerment, social inclusion) and (3) accountability (e.g. rule of law, transparency). The present challenge for agencies is to work on all three sets of issues, moving beyond a tendency to focus on civil and political rights and contribute to the realisation of economic and social rights, which are too simply equated with poverty reduction efforts.

\section{Assessing progress to date}

A number of bilateral agencies have moved beyond human rights policy statements and have explicitly adopted a rights-based label (e.g. DFID 2000a; NORAD 1999; NZAID 2002; Swedish Ministry for Foreign Affairs 1999); others are currently discussing whether they need to be making this change (e.g. SDC and Canadian International Development Agency - CIDA). The debate is very much alive today: in 2004, the Development Assistance Committee of the Organisation for Economic Cooperation and Development (OECD DAC) officially approved the work programme of a new human rights task force under its governance network; Germany adopted a human rights approach (German Federal Ministry for Economic Cooperation and Development 2004) and the Japan International Cooperation Agency adopted guidelines on environmental and social impact assessments, referring to the importance of human rights considerations in development planning (JICA 2004).

Some of the questions to be addressed and decisions that agencies need to make include:

- Should the overall agency goal be amended to reflect not just poverty reduction but also the realisation of human rights?

- Whether and how are human rights part of the international, regional and especially domestic legal framework affecting aid agencies (e.g. new global law in Sweden but how does the UK Human Rights Act affect DFID?)

- Whether it should be binding on all staff (as SDC's policy nominally is, though it cannot be enforced) or is a recommendation of good practice.

- How much to invest in institutional resources (building capacity through the appointment of staff or training)?

- Whether to change organisational norms and procedures (e.g. human rights analysis to inform country strategies).

- How much to invest in programme resources (new projects or budget support linked to human rights analysis and commitments)?

- Whether to assess the impact of assistance from a human rights perspective (and not just based on the achievement of the Millennium Development Goals).

Evidence of the extent to which bilateral agencies have not just adopted a rights-based approach at a rhetorical level, but have also internalised it, is limited. This is because the policy change is relatively recent; few evaluations and reviews have been undertaken and a change in values and mindset is hard to capture. A number of factors help to identify whether there has been a shift from rhetoric to practice and what has facilitated that change (Piron and Court 2003), namely:

- building on a favourable international and domestic political environment;

- gaining the commitment of senior officials, including ministers, agencies' senior managers, supported by effective champions of change lower down in the organisation;

- a clear and well-communicated policy statement, supported by guidance and tools to translate policy into dialogue and programmes;

- transferring resources into dialogue and projects;

- amending systems and procedures to internalise the approach;

- building internal staff capacity to understand and apply the approach.

Applying these criteria, Sida can be considered the bilateral agency having made the most progress towards internalising a rights-based approach as illustrated by the case study in Box 4 . 


\section{Box 4: Operationalising Sida's Democracy and Human Rights-based} Approach

Sweden has linked its development cooperation to human rights since the 1970s, but during 1997-8 made an official commitment to integrate them fully into all aspects of its foreign policy. The Swedish International Development Cooperation Agency (Sida), which is independent from the Ministry of Foreign Affairs, issued a number of documents to operationalise its 'democracy and human rightsbased approach'.

The overriding aim of Swedish aid is to raise the quality of life of poor people and democratic development is one of its six sub-goals. Sida both recognises that human rights are valuable in themselves as a development cooperation objective and also that a rights-based approach strengthens the effectiveness of development cooperation. Sida's approach starts from the international human rights framework, providing shared values and a common frame of reference with partners.

Sida has implemented its approach through policy dialogues, human rights programmes and mainstreaming in other sectors. About a quarter of its portfolio is spent on human rights and democracy activities. Sida has made a considerable investment in building staff capacity, through training and appointing specialised staff at headquarters and in the regions. New tools are being developed, such as a guidance document to undertake democracy and human rights assessments as part of every country analysis to feed into the development of its country strategies. Sectoral and regional policies have also been prepared (e.g. Eastern Europe, health and education) and women and children's rights are also a key human rights priority.

The backbone of Sida's approach is a strong domestic human rights culture, with public and party political support for human rights. There is strong evidence of a commitment to policy coherence nationally and globally: Sweden is one of the few countries to have a National Human Rights Action Plan covering the role of human rights in development cooperation and in 2004 it enacted a law on 'Shared responsibility: Sweden's policy for global development' putting human rights and poverty reduction at its centre in order to achieve equitable and sustainable development.

Source: Sida (1997a, 1997b, 2001a, 2001b, 2003); Swedish Government $(2002,2003)$.

\section{Resistance to rights-based approaches}

Though there seems to be a significant move towards rights-based approaches, some agencies that undertake human rights work have decided not to adopt this new label. AusAid, in particular, has a number of concerns including: the lack of common understanding of the term; the fear that it may lead to prioritising certain rights over others; the need for the approach to explicitly address the role and responsibility of developing countries and the constraints it may impose on aid delivery (AusAid 2001: 7-8). In the case of the US Agency for International Development, US foreign policy (including its distrust of international law and the non-recognition of the equal status of economic and social rights) explains the absence of an explicit policy orientation towards all human rights, let alone the decision to adopt a rights-based approach.
Its human rights orientation remains limited to civil and political rights, such as activities in the areas of the rule of law and political institutions.

Even when agencies adopt a rights-based approach at a policy level, there are real constraints to "internalising". Reviews of both SDC and DFID have shown a significant level of resistance (Piron and Court 2003; Piron and Watkins 2004).

The first set of reasons is operational. There is often reluctance to change on the part of staff, especially if a rights-based approach is seen as "the latest fad" that will eventually be replaced by something else. This is combined with concerns over workloads, which might be increased by new assessments tools or re-assessing programming objectives. Agencies may simply have too many policy statements and staff may feel unable to prioritise amongst them, or do not feel they have appropriate skills. Where there have been limited 
efforts at training or producing accessible guidance, the approach is seen as too technical, not developmental, or simply redundant: using a new discourse to legitimise what is already ongoing. Agencies' decentralisation also makes central policy orientation depend on the particular interest of staff on the ground. In addition to internal constraints, staff find it difficult to adopt new attitudes towards their partners and negotiate complex political dynamics (as other articles in this issue note, such as Hughes et al.).

Yet, the strongest source of opposition remains conceptual and strategic: human rights are often not seen as constituting an appropriate framework to guide agencies' work. This is in part explained by internal competition with other dominant frameworks permeating the goals and operations of agencies (such as basing development assistance on poverty reduction strategies or assessing the quality of policies based on their impact on growth prospects). The normative nature of rights-based approaches is itself a source of rejection, in particular its "moralising" tendency, resulting in rejection of what is seen as too naive. This is captured in Uvin's surprise 'at the amount of skepticism, if not outright hostility, that still prevails in much of the development community toward human rights' (Uvin 2004: 47).

\section{Challenges ahead}

Moving towards a rights-based approach is, however, not only an internal challenge for agencies. Looking at the nature of the international aid discourse, human rights do not constitute the mainstream normative framework guiding aid. This is so at the level of the overall objective of aid, how progress is measured and how relations with partners are managed.

In the words of AusAid, also describing the current aid consensus, "poverty reduction and sustainable development and not the advancement of specific human rights per se, is the driving force behind the make-up and management of the
Australian aid program' (AusAid 2001: 11). Unless the realisation of all human rights is equated with poverty reduction, the two remain separate (but related) objectives. In a policy context where growth is seen as the primary source of poverty reduction over the longer term, interventions to combat discrimination, redistribute resources to tackle inequality or protect human dignity are often seen as costly or political side-concerns.

Human rights and poverty reduction are also measured differently. The Millennium Development Goals are used to assess progress with the effectiveness of the aid effort. Yet, they are not identical to human rights norms, standards and principles. As global, utilitarian measures they have created powerful prioritisation incentives within aid agencies, but can be achieved without paying sufficient attention to processes or to the groups that are systematically left behind (see Shetty, this issue).

The current aid discourse privileges "partnerships" to achieve poverty reduction and aid is meant to be increasingly based on a government's own poverty reduction strategies. While this may eventually lead to more equitable relations between donors and recipients, for example through the use of contractual models whereby both parties can be held accountable (Piron 2004; Uvin 2004), references to mutual accountability and shared responsibility can easily take place in the absence of genuine efforts to operationalise human rights obligations which are often absent from poverty reduction strategies and their monitoring processes.

In all these domains and more, human rights are not yet informing the setting of development goals, used to assess processes and outcomes, or shaping relations between partners. If rights-based approaches are to be more than a metaphor, human rights need to be accepted as the shared values of development partnerships and, at the very least, used as the minimum criteria for principled behavior by donors (Uvin 2004: 119).

\section{Notes}

* This article draws on the published findings of various projects funded by the UK Department for International Development (DFID), the Swiss Agency for Development and Cooperation (SDC) and the Office of the United Nations High Commissioner for Human Rights (OHCHR). It does not represent the views of these agencies. Tammie O'Neil provided research assistance. 


\section{References}

Alston, P., 1998, 'What's in a name: does it really matter if development policies refer to goals, ideals or human rights?', in H. Helmich and E. Borghese (eds), Human Rights in Development Cooperation, SIM Special 22, Paris: Organisation for Economic Cooperation and Development Centre

Alston, P., 1985, 'The shortcomings of a "Garfield the Cat" approach to the right to development', California Western International Law Journal, Vol 15

AusAid, 2001, 'Putting Things to Rights: The Use of Foreign Aid to Advance Human Rights in Developing Nations', submission to the Human Rights Sub-Committee of the Joint Standing Committee on Foreign Affairs, Defence and Trade on its Inquiry into the Link Between Aid and Human Rights, February

Baaré, A., Shearer, D., Uvin, P. with a contribution from Scherrer, C., 1999, The Limits of Scope for the Use of Development Assistance Incentives and Disincentives for Influencing Conflict Situations: Case Study, Rwanda, DAC Informal Task Force on Conflict, Peace and Development Cooperation, September

CIDA (Canadian International Development Agency), 1996, Government of Canada Policy for CIDA on Human Rights, Democratization and Good Governance, December, Gatineau, Quebec: CIDA

Carothers, T., 1999, Aiding Democracy Abroad: The Learning Curve, Washington, D.C.: Carnegie Endowment for International Peace

Danida (Danish International Development Agency), 2003, A World of Difference: The Government's Vision for New Priorities in Danish Development Assistance 2004-2008, Copenhagen: Danida

DFID, 2000a, Eliminating World Poverty: Making Globalisation Work for the Poor, White Paper on International Development, London: Department for International Development

DFID, 2000b, Realising Human Rights for Poor People, London: Department for International Development

DFID, 1997, Eliminating World Poverty: A Challenge for the 21st Century, White Paper on International Development, November, London: Department for International Development

Dutch Advisory Council on International Affairs (DACIA), 2003, 'A Human Rights Based Approach to Development', April, The Hague: DACIA
Finnish Ministry for Foreign Affairs, 2000, Democracy and Human Rights: A Pathway to Peace and Development, Helsinki: Ministry for Foreign Affairs

Frankovits, A. and Earle, P., 2000, Working Together: The Human Rights Based Approach to Development Cooperation, Stockholm Workshop, 16-19 October 2000, Parts 1 and 2

German Federal Ministry for Economic Cooperation and Development, 2004, 'Every person as a right to development: German development policy approach to respecting, protecting and fulfilling political, civil, economic, social and cultural human rights', BMZ Concepts, Development policy action plan on human rights 2004-2007, July

Government of Australia, 1998, Minister of Foreign Affairs, 8th Annual Statement to Parliament on Australia's Development Cooperation Programme, December

Ignatieff, M., 2003, 'Moral globalisation and its discontent', presentation at a conference on human rights organised by the Institute for Public Policy Research, 25 November, London Japan International Cooperation Agency (JICA), 2004, Guidelines on Environment, April, Tokyo: JICA

NORAD, 2001, Handbook in Human Rights Assessment. State Obligations, Awareness and Empowerment. Oslo: Norwegian Agency for Development Cooperation

NORAD, 1999, NORAD Invests in the Future. NORAD's Strategy for 2000-2005, Oslo: Norwegian Agency for Development Cooperation

NZAID (New Zealand's International Aid \& Development Agency), 2002, Human Rights Policy Statement, Wellington: NZAID

Piron, L.-H., 2004, 'The right to development: study on existing bilateral and multilateral programmes and policies for development partnership', Report Commissioned by the Office of the High Commissioner for Human Rights, E/CN.4/Sub.2/ 2004/15, 3 August

Piron, L.-H., 2003, Learning from the UKDepartment for International Development's Rights-Based Approach to Development Assistance, Bonn: German Development Institute and London: Overseas Development Institute

Piron, L.-H., 2002, The Right to Development: A Review of the Key Issues and Recommendations to the UK Department for International Development, April, London: Overseas Development Institute 
Piron, L.-H. and Court, J., 2003, Independent Evaluation of the Swiss Agency for Development and Cooperation Human Rights Policy Guidelines and Rule of Law Concept Document, London: Overseas Development Institute

Piron, L.-H. and Watkins, F., 2004, DFID Human Rights Review, London: Overseas Development Institute

Pratt, B., 2003, 'Rights or values?', viewpoint, ONTRAC 23, January 2003, International NGO Training and Research Centre (INTRAC)

SDC, 2004, Creating the Prospect of Living a Life of Dignity. Principles Guiding the SDC in its Commitment to Fighting Poverty, Geneva: Swiss Agency for Development and Cooperation

SDC, 1997, Promoting Human Rights in Development Cooperation, Geneva: Swiss Agency for Development and Cooperation

Sida, 2003, Country Strategy Development: Guide for Country Analysis from a Democratic Governance and Human Rights Perspective, Stockholm: Swedish International Development Cooperation Agency

Sida, 2001a, A Democracy and Human Rights-Based Approach in Swedish Development Cooperation, Stockholm: Swedish International Development Cooperation Agency

Sida, 2001b, Education for All, A Human Right and a Basic Need, Stockholm: Swedish International Development Cooperation Agency

Sida, 1997a, Justice and Peace: Sida's Programme for Peace, Democracy and Human Rights, Stockholm: Swedish International Development Cooperation Agency

Sida, 1997b, Sida at Work: Sida's Methods for Development Cooperation, Stockholm: Swedish International Development Cooperation Agency

Swedish Government, 2003, 'Shared responsibility: Sweden's policy for global development', Government Bill 2002/03, Stockholm: Swedish Government

Swedish Ministry of Foreign Affairs, 1999, 'Democracy and human rights in Sweden's Development Cooperation', Government Communication SKR 1997/98, Stockholm: Swedish Ministry of Foreign Affairs
Swiss Government, 1993, Report of the Federal Council on Switzerland's Foreign Policy, 29 November, Berne: Swiss Government

Theis, J., 2004, Promoting Rights-Based Approaches: Experiences and Ideas From Asia and the Pacific, Bangkok/Stockholm: Save the Children Sweden United Nations, 2003, Report on the Second Interagency Workshop on Implementing a Human Rights-Based Approach in the Context of UN Reform, 'Attachment 1: The human rights based approach to development cooperation: towards a common understanding among the UN agencies', 5-7 May, Stamford, CT: UN

United Nations, 2002, Report of the International Conference on Financing for Development, Monterrey, Mexico: UN

United Nations, 2001, 'Road map towards the implementation of the United Nations Millennium Declaration', Report of the Secretary General, A/56/326, Annex: Millennium Development Goals, 6 September, New York: UN

United Nations, 2000, United Nations Millennium Declaration - Resolution Adopted by the General Assembly A/Res/55/2, New York: UN

United Nations, 1997, Reforming the UN: A Programme for Reform A/51/950, New York: UN

United Nations, 1993, Vienna Declaration and Programme of Action, A/CONF.157/23, New York: UN

UNDP, 2000, Human Development Report: Human Rights and Development, New York: United Nations Development Programme

UNDP, United Nations Office of the High Commissioner for Human Rights and Royal Ministry of Foreign Affairs of Norway, 1998, 'Human development and human rights', Report of the Oslo Symposium, 2-3 October, New York: United Nations Development Programme

Uvin, P., 2004, Human Rights and Development, Bloomfield: Kumarian Press

World Bank, 1998, Development and Human Rights: The Role of the World Bank, World Bank: Washington, D.C. 